\title{
MODEL PERMAINAN KINESTETIK UNTUK MENINGKATKAN KEMAMPUAN MATEMATIKA AWAL PADA ANAK USIA DINI
}

\author{
SETIYO UTOYO ${ }^{1}$-IRVIN NOVITA ARIFIN ${ }^{2}$ \\ Universitas Negeri Gorontalo, Indonesia \\ Email: setyo.utoyo@gmail.com \\ irvin.novita@gmail.com
}

\begin{abstract}
: the purpose of this research is to develop a model play kinesthetic in improving early mathematical ability in group B TK Damhil Gorontalo.

The research of method used is the development of a model $(R \& D)$ developed by Borg \& Gall.

The design of model development is done through the requirement analysis phase, product development and testing. The first phase trial was conducted in TK Damhil Gorontalo with a number of students 20. The second phase trial was conducted in TK Al Murqi Gorontalo with a number of students 20. The effectiveness of the model test showed a significant increase in the process of assisting children with early mathematical abilities in early childhood. The results of this study generally illustrate that the kinesthetic play model is easy and practical to use. The kinesthetic play model can improve early mathematical abilities in early childhood
\end{abstract}

Keywords: Early Mathematics, Kinesthetic Play

Abstrak, Tujuan penelitian ini untuk mengembangkan model permainan kinestetik dalam meningkatkan kemampuan matematika awal pada kelompok B TK Damhil Gorontalo.

Metode penelitian yang digunakan adalah pengembangan model (R \& D) yang dikembangkan oleh Borg \& Gall. Disain pengembangan model dilakukan melalui tahap analisis kebutuhan, pengembangan dan pengujian produk. Uji coba tahap pertama dilakukan di TK Damhil Gorontalo dengan sejumlah murid 20. Uji coba tahap ke dua dilakukan di TK Al Murqi Gorontalo dengan sejumlah murid 20.Efektivitas uji model menunjukkan adanya peningkatan yang signifikan dalam proses membantu anak-anak dengan kemampuan matematika awal pada anak usia dini. Hasil penelitian ini secara umum menggambarkan bahwa model permainan kinestetik mudah dan praktis digunakan. Model permainan kinestetik dapat meningkatkan kemampuan matematika awal pada anak usia dini.

Kata kunci: Matematika awal, Permainan Kinestetik

\section{PENDAHULUAN}

$$
\text { Kemampuan matematika }
$$

menjadi salah satu fenomena yang sangat hangat dibicarakan semua kalangan terutama di kalangan orangtua. Salah satu tujuan orangtua memasukkan anaknya
kelembagaPAUD adalah agar anaknya mampu menguasai matematika. Masih banyak orangtua yang menganggap bahwa anak yangcerdas dapat menguasai atau mampu calistung (baca, tulis dan berhitung) sedini mungkin. Para 
orangtua memiliki kekawatiran bahwa ketika anaknya melanjutkan pendidikan sekolah lanjutan akan terhalang dikarenakan anaknya belum menguasai kemampuan matematika, sebab saat masuk sekolah lanjutan anak harus melalui serangkaian tes, dimana salah satunya kemampuan matematika.

Berdasarkan hasil studi pendahuluan di beberapa TK di wilayah Gorontalo (TK Damhil, TK Negeri Pembina Kihajar Dewantoro, TK Al Murqi, TK Al Islah, TK Kartika Wirabuana, dan TK Raudhatul Jannah) pada semester II tahun ajaran 2016/2017 dan hasil wawancara dengan guru serta kepala sekolah TK, menunjukkan bahwa masalah tuntutan orangtua dalam memperhatikan kemampuan matematika anaknya rendah, ini terlihat dari hasil kerja anak tiap hari. Kenyataan tersebut juga diperkuat lagi ketika peneliti melakukan evaluasi awal dari rencana kegaiatan harian semester II tahun ajaran 2016/2017 pada kelompok B yang berjumlah 20 anak. Hasil yang diperoleh tenyata dari 20 orang anak sebagian besar kemampuan matematika awal belum berkembang sesuai harapan. Hal ini diduga disebabkan kurang penguasaan guru dalam menyampaikan pembelajaran dan agak bersifat kaku dalam proses pembelajaranya. Wajar bila anak semakin menjauhi bidang pengembangan matematika ini. Hal ini menyebabkan guru merasa dilematis untuk menggunakan permainan dalam pemberian stimulasi perkembangan matematika disetiap kegiatan pembelajaran.

Permasalahan kemampuan matematika awal pada anak usia dini diantaranya ditemui di TK Damhil kota Gorontalo yaitu dari ke lima indikator kemampuan matematika awal anak yang penelti amati yaitu klasifikasi, menjodohkan, mengurutkan, membandingkan dan membilang hasil obeservasi 20 anak diperoleh data hanya $27 \%$ dari keseluruhan anak memiliki kemampuan matematika awal kriteria baik, $42 \%$ keseluruhan anak memiliki kemampuan matematika awal kriteria cukup, dan $31 \%$ dari keseluruhan anak memiliki kemampuan matematika awal dengan kriteria kurang. Berdasarkan 
data tersebut maka kemampuan matematika awal anak kelompok B1 TK Damhil Kota Gorontalo masih dalam katagori rendah (observasi April 2017).

Hasil penelitian yang dilakukan Mooney, et.al (2009) bahwa anak belajar matematika melalui permainan dan eksplorasi seperti bercerita, bernyanyi, kinestetik, imajinatif maupun bermain peran. Kegiatan belajar matematika melalui permainan dan eksplorasi lebih menarik dan menyenangkan siswa terlibat dalam aktifitas-aktifitas yang mencakup dunianya. Berdasarkan latar belakang tersebut peneliti tertarik untuk merancang model permainan khususnya dalam pengembangan kemampuan matematika anak usia dini.

\section{KAJIAN TEORITIK}

\section{Konsep Kemampuan Matematika Anak Usia Dini}

Definisi matematika secara umum merupakan kemampuan yang muncul dari berpikir dan dikuasai oleh seorang anak dalam menyelesaikan berbagai persoalan masalah yang dihadapinya dalam kehidupan sehari-hari. Seperti dalam kegiatan pengenalan matematika anak usia dini diantaranya mengklasifikasi benda berdasarkan warna, bentuk dan ukuran, membuat pola-pola, urutan dan ukuran, konsep bilangan, korespondensi satusatu, konsep membandingkan, geometri, estimasi, mata uang, waktu dan menggunakan media-media kongkrit sebelum mengoperasikan simbol-simbol abstrak, serta melakukan interaksi melalui bermain. Menurut Kennedy (2008) konsep matematika untuk anak usia dini yaitu a) matching and discriminating, comparing and contrasting, b) classifying, sorting and grouping, c) ordering, sequence and seriation.

Berdasarkan uraian teori di atas dijelaskan bahwa kemampuan matematika adalah kemampuan matematika anak yang diperoleh dari berbagai proses. Kemampuan matematika tersebut dapat diaplikasikan dalam bentuk konsep untuk memecahkan masalah yang diwujudkan dalam pengetahuan sepertiklasifikasi, mencocokan, mengurutkan, membandingkan, 
membilang. Pengalaman matematika awal ini merupakan keterampilan dasar untuk memahami konsep matematika selanjutnya.

\section{Permainan Kinestetik}

Musfiroh (2008) mengatakan bermain adalah kegiatan yang dilakukan atas dasar suatu kesenangan dan tanpa mempertimbangkan hasil akhir. Kegiatan bermain dapat dilakukan secara suka rela, tanpa paksaan atau tekanan dari pihak luar (Hurlock, 1997). Santrock (2012) menjelaskan bermain adalah suatu kegiatan yang menyenangkan yang dilakukan untuk kepentingan kegiatan itu sendiri.

Freud dan Erikson dalam Santrock (2012) bermain adalah suatu bentuk penyesuaian diri manusia yang sangat berguna menolong anak menguasai kecemasan dan konflik. Piaget dalam Santrock (2012) menjelaskan permainan merupakan suatu media yang meningkatkan perkembangan kognitif pada anak-anak. Mengacu pada berbagai pendapat tersebut permainan kinestetik dalam penelitian ini adalah permainan yang dilakukan dalam bentuk gerak kinestetik dalam meningkatkan kemampuan matematika awal anak usia dini.Oleh karena itu, kemampuan gerak atau motorik skill merupakan kemampuan melakukan gerakan secara efisien dan efektif. Keterampilan secara umum adalah sebuah istilah yang sering dikaitkan seseorang sebagai kemampuan untuk melakukan tujuan yang spesifik (Ricard, 1998).

Model Kemampuan Matematika Anak Usia Dini Yang Dikembangkan Melalui permainan Kinestetik

Pengembangan kemampuan matematika ini dilakukan melalui kegiatan yang melibatkan anak secara langsung dalam permainan yang sudah peneliti rancang sebelumnya. Pembelajaran berupa permainan yang melibatkan pergerakan motorik kasar pada anak, dalam kegiatan tersebut dirancang dengan mengacu pada pengembangan konsep-konsep matematika yang disesuaikan dengan usia anak.

Permainan kinestetik ini di dalamnya disimulasikan dengan permainan gerak motorik pengusaan keseimbangan, gerakan yang dinamis 
dan keterampilan motorik. Sehingga anak akan merasa nyaman dan senang serta tertarik untuk mengikuti kegiatan tersebut, dengan kondisi seperti ini akan memudahkan anak dalam penyerapan informasi baru mengenai konsep-konsep matematika secara sederhana.

\section{METODE PENELITIAN}

Penelitian ini menggunakan prosedur disain pengembangan model ( $\mathrm{R}$ and $\mathrm{D})$. Metode yang dijadikan acuan adalah model penelitian Borg and Gall modifikasi Abdullah, 2008 yang terdiri atas lima langkah yaitu: (1) melakukan analisis produk yang akan dikembangkan, (2) mengembangkan produk awal, (3) validasi ahli dan revisi, (4) uji coba lapangan skala kecil dan revisi produk, dan (5) uji coba skala besar dan produk akhir.

$$
\text { Pengambilan sampel }
$$

menggunakan teknik Purposive Sampling. Sampel penelitian dipilih setelah peneliti melakukan studi pendahuluan ke beberapa TK yang ada diwilayah Gorontalo. Adapun TK yang dijadikan sampel pada uji coba pertama di TK Damhil, selanjutnya uji coba kedua dilakukan di TK Al Murqi dan Al Izlah

Teknik analisis data yang digunakan dengan data kualitatif dan kuantitatif. Untuk data kualitatif dianalisis pada saat pengumpulan data berlangsung dan setelah selesai pengumpulan data periode tertentu dengan cara merangkum data untuk memilih hal-hal yang pokok dan penting. Untuk data kuantitatif diperoleh dari hasil penyebaran angket dianalisis menggunakan teknik analisis deskriptif dengan presentase, sedangkan data hasil test (pre test dan post test) kemampuan matematika awal anak usia TK dianalisis dengan uji-t.

\section{HASIL DAN PEMBAHASAN}

Hasil pelaksanaan penelitian diperoleh dari hasil studi pendahuluan yang dilakukan di beberapa TK yang ada di wilayah Gorontalo, ditemukan fakta bahwa guru belum mempunyai metode khusus dalam menangani masalah kemampuan matematika awal pada anak. Cara-cara yang dilakukan selama ini hanya dengan pembelajaran konvensional, seperti 
guru lebih banyak menyampaikan dengan instruksi, terbiasa dengan pembiasaan menulis di papan tulis, di samping itu guru masih banyak menggunakan tradisi lama yang hanya fokus pada kegiatan di dalam kelas, belum menjadikan bermain di luar kelas khususnya dalam pembelajaran matematika.

Jadi dapat disimpulkan bahwa model permainan kinestetik merupakan model inovatif untuk meningkatkan kemampuan matematika awal di wilayah Gorontalo.Model permainan kinestetik dirancang melalui proses kajian teoritis yang mendalam serta akan dilakukan beberapa kali proses uji coba di lapangan.

\section{Hasil uji coba tahap I}

Berdasarkan uji coba tahap I model permainan kinestetik untuk meningkatkan kemampuan matematika anak di TK Damhil Gorontalo telah menghasilkan revisi produk: (1) Pada pemilihan jenis permainan yang tepat menjadi salah satu penyebab terlaksananya atau tidaknya permainan dengan baik. Dalam prakteknya ada 10 permainan yang dicobakan dan disesuikan dengan jadwal pertemuan berlangsung. Adapun jenis permainan yaitu (a) lari tangkas, (b) lari Zig-zag, 3) Lari Bersama Bendera, (c) Tebak dan Terka, (d) Lempar Bolamu) (e) Lompati Segitigamu, (f) Lari Estafet, (g) Berjinjit di Gambar Rumah, (h) Dimana Rumahmu, (i) Merayap Dibawah Rintangan;

(2) Media yang digunakan dalam permainan terlihat cukup efektif dan menyenangkan sebagai olah fisik anak dengan aturan permainan yang dipandu; (3) Materi, media dan alat, bahasa tulisan juga mudah dipahami oleh guru yang menggunakan pada saat penilaian. Dalam penetapan format dan indikator perkembangan kemampuan matematika awal pada anak sudah melalui proses revisi dengan masukan ahli dan pakar;

(4) Desain permainan yang digunakan sudah dirancang sedemikian rupa, sehingga dapat melatih kemampuan matematika awal anak.

Disain yang dibuat juga sudah mempertimbangkan tingkat kesulitan bagi anak untuk setiap pertemuan dan mereka dapat mengikutinya dan 
mempraktekan dengan baik; (5) Hasil peningkatan kemampuan matematika anak yang terjadi dilakukan dengan cara membandingkan hasil yang diperoleh ketika asesmen awal dengan asesmen akhir.

Asesmen awal dilakukan sebelum model permainan diperkenalkan kepada anak, sedang asesmen akhir dilakukan setelah anak mengikuti permainan. Dari hasil asesmen akhir pelaksanaan uji coba tahap I model permainan kinestetik terjadi peningkatan matematika awal pada anak dibandingkan dengan asesmen awal. Dengan hasil pelaksanaan uji coba model permainan kinestetik dalam pengembangan kemampuan matematika anak di TK Damhil Gorontalo menunjukkan fakta yang menggembirakan. Anak-anak terlihat senang mengikuti model pembelajaran ini, dan hasil belajar matematika mereka meningkat secara signifikan.

Berdasarkan hasil yang diperoleh tersebut, maka pada tahap selanjutnya peneliti akan melakukan pengembangan model dengan melakukan ujicoba tahap II di TK Al Murqi.

\section{Hasil uji coba tahap II}

Dalam pelaksanaan uji coba tahap II berbagai kekurangan yang dialami pada uji coba sebelumnya sudah tidak ditemukan lagi. Berbagai hal yang menunjang kemudahan dan kepraktisan model permainan ini adalah (1) tersedia disain permainan kinestetik mudah dipahami guru, tersedianya media setiap permainan menarik perhatian anak, (2) macam-macam permainan yang dipraktekkan menarik dan dapat membantu guru mengontrol fisik dan kinestetik anak. (3) perangkat asesmen yang disediakan mudah dipahami dan praktis digunakan.

Berdasarkan hasil penelitian ditemukan bahwa; penanganan masalah pembelajaran kemampuan matematika awal pada anak usia dini memerlukan penguasaan guru, baik dalam mengoptimalkan media agar yang lebih menarik dan menyenangkan, maupun dalam menggunakan pendekatan sosial emosional. Penyampaian materi seharusnya sesuai konsteks 
kehidupan anak, serta menciptakan kreasi dan imajinatif dalam pembelajaran. Jadi pembahasan kemampuan matematika awal yang dilakukan dapat tercapai sesuai target dikarenakan pembelajaran permainan kinestetik merupakan permainan yang cocok digunakan dalam meningkatkan kemampuan matematika awal anak TK.

Disamping itu, strategi dengan permainan tidak hanya berdampak pada meningkatkan kemampuan matematika awal saja, namum aspek penting lainnya juga mampu dikembangkan secara bersamaan seperti, sosialisasi anak berkembang, keberanian, kemandirian, attitude anak dalam berkomunikasi dengan temannya, motorik skill, olah fisik, bahasa,dan beberapa aspek lainnya.

Karakteristik anak usia dini yang harus menjadi pertimbangan adalah anak usia dini itu suka bermain, mereka memiliki dunia yang disebut dunia bermain. Oleh sebab itu jika membuat model pembelajaran untuk anak usia dini maka sebaiknya dirancang dalam bentuk permainan.

\section{KESIMPULAN}

Hasil studi pendahuluan dan penelitian diperoleh kesimpulan sebagai berikut: (1) Guru belum mempunyai metode khusus dalam menangani masalah kemampuan matematika awal pada anak. Caracara yang dilakukan selama ini hanya dengan pembelajaran konvensional, seperti guru lebih banyak menyampaikan dengan instruksi, terbiasa pembiasaan menulis dipapan tulis, disamping itu guru masih banyak menggunakan tradisi lama yang hanya fokus kegiatan didalam kelas menjadi bermain diluar kelas khususnya dalam pembelajaran matematika.

(2) Model permainan kinestetik dirancang melalui proses kajian teoritis yang mendalam serta beberapa kali proses uji coba dilapangan. Model dikembangkan dengan memperhatikan karakteristik anak usia dini serta memfasilitasi gaya belajar yang berbeda-beda dan sudah melalui proses validasi ahli seperti tersedia disain permainan kinstetik, tersedianya media setiap permainan, tersedianya macammacam permainan yang dipraktekkan 
dan tersedianya perangkat asesmen pembelajaran. Hasil rekomendasi teman sejawat dan validasi ahli diperoleh kesimpulan bahwa produk model permainan kinestetik praktis dan efektif untuk digunakan guru, serta efektifitas hasil model yang dikembangkan.

(3) Hasil uji coba model permainan kinestetik tahap pertama dilakukan tepatnya pada Kelompok B TK Damhil Kota Gorontalo, membuktikan bahwa secara efektif model permainan kinestetik dapat meningkatkan kemampuan matematika awal anak usia dini.

\section{DAFTAR PUSTAKA}

D. Gall, Meredith, Joy Gall, and Wolter R. Borg, Education Research and Introduction, Boston: Pearson Education, Inc, 2003.

Jamaris Martini, Kesulitan Belajar "Perspektif, Asesmen dan Penanggulangannya" Jakarta: Yayasan Penamas Murni, 2014.

Leonard M. Kennedy, Steve Tipps, Art Johnson, Guiding Children's Learning of Mathematic, United States of America: Thomson Wadsworth, 2008.

Minetola R. Janice, Robert G. Xiegentuss, And J. Kent Chirman. Teaching Young
Childrens Mathematics. New York: Rouledce. (on line book), First Published 2004.

Musfiroh Tadkiroatun. Cerdas Melalui Bermain (cara Mengasah Multiple Intelligence Pada Anak Usia Dini). Jakarta: Grasindo, 2008.

Mooney, Claire., Briggs, Mary., Fletcher, Mike., Hansen, Alice., Mc Cullouch, Judith..Primary Mathematics: Teaching, Teory, and Practice. Exeter: Learning, 2009.

National Council of Teachers of Mathematics, Principles and standards for school mathematics, Reston, VA: Author, 2000.

Nurani Yuliani \& Bambang Sujiono, Bermain Kreatif Berbasis Kecedasan Jamak. Jakarta: indeks, 2010.

Oers Van Bert. Are You Sure Stimulation Mathmatical Thingking Gurung Young Childrens Play. University Amsterdam, 2011.

Ontario.

www.edu.gov.on.ca/eng/literacy numeracy/inspire/. Capacity Buliding Series Maximizing Student Mathematical Learning in the Early Years. ISSN: 1913 8482 (Print) ISSN: 19138490 (Online)ca/eng/literacynumeracy /i. 2011.

Rosalind Charlesworth and Karen K. Lind, Math \& Science for Young Children, United States of 
Amerika: Delmar Publisher Inc, 1990.

Russefendi E.T, Pengantar untuk membantu guru mengembangkan kompetensinya dalam pembelajaran matematika untuk meningkatkan CBSA, Bandung: Transito, 2001.

Subarinah, Inovasi Pembelajaran Matematika SD, Jakarta: Depdiknas, 2006.

Susan Sperry Smith. Early Childhood Mathematics. United States of America: Pearson. Bandung: Remaja Rosdakarya, 2009.

Santrock, John W. Life-span Development. 13 th Edition. University of Texas, Dallas : Mc Graw-Hill, 2012.

Schwartz. Sydney L. Teaching Young Children Mathematics, Westport, CT: Praeger, 2005.

Utoyo Setiyo, Peningkatan Kemampuan Matematika Permulaan Melalui Pendekatan Problem Solving, Jakarta: PPs UNJ, 2014.

Utoyo Setiyo, Pembelajaran Kinestetik Pada Anak Usia Dini, Gagasan Menuju Tindakan, Gorontalo: Prosiding National Seminar and Internasional Conference, Volume I Nomor 01 September 2015. 